\title{
PENGARUH KECEPATAN DRUM PROSES TERHADAP SIFAT FISIK KULIT KAMBING UNTUK SARUNG
} TANGAN GOLF

\author{
Sugeng Supriadi*, Eddy Purnomo*, Meiyanti**
}

\section{ABSTRACT}

Fifteen pieces of wet blue were devided into three groups of equal number of pieces. All of the group were processed into glove leather with drum rotational speed of 15 RPM. 20 RPM and 25 RPM resfectively. Analysis of varians showed that the speed effected the tensile strength, tensile strech. elongation, and tear strength of the leather obtained. The leather processed at 25 RPM gave the highest tensile strength $(138,56 \mathrm{~kg} / \mathrm{cm} 2)$ tensile stretch $(29,30 \mathrm{~mm})$, elongation $(58,60 \%)$, and tear strength $(30,53 \mathrm{kh} / \mathrm{cm})$

\section{INTISARI}

Penelitian ini bertujuan untuk mengetahui pengaruh kecepatan drum terhadap sifat fisik kulit sarung tangan. Lima belas lembar kulit wet blue dibagi menjadi tiga kelompok yang sama jumlahnya. Masing-masing kelompok diproses menjadi kulit sarung tangan dengan variasi kecepatan drum 15 RPM 20 RPM, dan 25 RPM. Analisa variansi menunjukkan terdapat perbedaan nyata diantara perlakuan lerhadap kekuatan tarik, pertambahan mulur, persen perfambahan mulur dan ketahanan sobek. Hasil penelitian menunjukkan bahwa kulit yang diputar dengan kecepatan 25 RPM memberikan nilai ratarata tertinggi pada kekuatan tarik, pertambahan mulur, persen pertambahan mulur, dan ketahanan sobek masing-masing sebesar $138,56 \mathrm{~kg} / \mathrm{cm} 2,29,30 \mathrm{~mm}, 58,60 \%$ dan $30,53 \mathrm{~kg} / \mathrm{cm}$

\section{PENDAHULUAN}

Efektifitas proses penyamakan, penyamakan ulang, peminyakan, dan pewarnaan dasar selain ditentukan oleh faktor kombinasi bahan yang digunakan, suasana lingkungan seperti, pH cairan, konsentrasi bahan kimia, temperatur, media proses (cairannya), lamanya proses, juga dipengaruhi oleh faktor fisik, terutama kecepatan putaran drum tempat proses dilakukan, yang berhubungan erat dengan diameter drum dan volume total drum tersebut.

Proses pengolahan kulit yang menggunakan drum memperoleh aksi mekanik karena putaran drum yang terus menerus selama waktu yang tertentu. Pada saat drum berputar, kulit akan terangkat dan pada titik tertentu kemudian jatuh pada dasar drum. Peristiwa ini terjadi berulang-ulang yang menimbulkan efek bengkukan, kompresi, dan pengendoran-pengencangan sehingga timbul aksi mekanik seperti perasan, tekanan dalam ruang antara serat yang berubah-ubah, dan mengakibatkan

*) Akademi Teknologi Kulit, Yogyakarta

*) Balai Besar Penelitian dan Pengembangan Industri Barang Kulit, Karet dan Plastik, Yogyakarta 
aliran dari cairan eksterna ke corium kulit. Pada saat itulah terjadi kontak atau reaksi kimia antara cairan proses, yang mengandung camppuran bahan kimia, dengan struktur serat protein internal aktif. Aktivitas reaksi tersebut menjadi efektif bila dituunjaang dengan kondisi optimal reaksi seperti $\mathrm{pH}$ cairan, temperatur, dan konsentrasi bahan kimia.

Walaupun aksi mekanik sangat penting untuk mempercepat proses namun aksi mekanik yang berlebihan kurang menguntungkan, tidak hanya membuang energi juga dapat merusak struktur kulit seperti rajah berkerut, rajah yang lepas, bentuk berubah, kulit yang tidak rata (menggeliat), dan serat kulit yang semakin melonggar. (Sharphouse. JH'89).

Aksi mekanik yang kurang efektif dapat disebabkan oleh putaran drum yang terlalu lambat atau terlalu cepat.

Pada putaran drum yang sangat cepat gaya centrifugal yang ditimbulkan lebih besar dibanding gaya grafitasi norma, sehingga kulit tetap tertahan pada dinding drum dan terus mengikuti putaran drum, gaya mekanis yang demikian tidak memberikan pengaruh pada difusi cairan eksternal kedalam serat kulit, titik kritis ini disebut Critical

\section{2,4}

$$
\text { Speed }(\mathrm{Nc}) \text { dimana } \mathrm{Nc}=\frac{\ldots}{\sqrt{\text { diameterdrum }}}
$$

Sebaliknya putaran yang terlalu lambat menyebabkan gaya centrifugal juga kecil dibandingkan dengan grafitasi bumi, akibatnya kulit tidak dapat terangkat dan hanya bergerak pada dasar drum sehingga dampak aksi mekaniknya sangat kecil. Kecepatan ini disebut Rolling Speed (NR) yang besarnya 1/2 Nc.

Apabila dibuat dalam interval kecepatan, maka kecepatan proses penyamakan ulang, peminyakan, dan pewarnaan berada dalam interval Critical Speed dan Rolling Speed.

Menurut Sharphouse (1989), kecepatan Rotasi drum yang dapat memberikan dampak aksi mekanik pada kulit secara maksimal adalah $\pm 66 \%$ dari Critical Speed biasa disebut sebagai Maksimum Impact Speed (NI).

Dalam penelitian ini digunakan kulit sarung tangan sebagai contoh pengujian karena kulitnya sangat tipis sehingga kepekaannya tinggi terhadap perubahan sifat fisik dan lebih mudah untuk diamati.

\section{MATERI DAN METODE PENELITIAN}

\section{Materi Penelitian}

1. Bahan baku kulit kambing, Wet blue sebanyak 15 lembar, dibagi dalam tiga kelompok yang sama jumlahnya dengan rata-rata luas 5,5 square feet, tebal 1,2 $\mathrm{mm}$, jenis kelamin betina, kualitas III.

2. Peralatan berupa drum stainlesteel dengan ukuran lebar $80 \mathrm{~cm}$, diameter 112 $\mathrm{cm}$.

\section{Metode Penelitian}

1. Teknik Sampling

Kulit diusahakan diambil dari satu kelompok, kualitas, luas, tebal, jenis kelamin. dan satu partai Wet blue.

2. Proses Pengolahan

Kulit Wet blue diproses menjadi kulit sarung tangan menggunakan drum yang divariasi kecepatan putarnya, masing-masing 15 RPM. 20 RPM, dan 25 RPM.

Adapun formulanya sebagai berikut :

a. Timbang Berat Wet blue

b. Pembasahan Ulang

R/ 200\% air, 1\% Asam Formiat, 0,5\% Surfaktan Non Ionik; Putar bersama kulit selama 30 menit; buang cairannya; $\mathrm{pH}$ akhir $=3,2$

- c. Pewarnaan Dasar

$\mathrm{R} / 200 \%$ air panas $(60-80) \mathrm{C} ; 2 \%$ cat Asam hitam dibuat pasta encer kemudian masukkan dalam drum yang sedang berputar. Putar drum selama 10 menit; tambahkan $\pm 1,5 \%$ Asam Formiat. Putar 15 menit, cairan menjadi bening, kemudian buang.

d. Pengetahuan, tebal 0,7-0,8 mm.

e. Penimbangan, ...kg.

f. Penyamakan Ulang

R/ $80 \%$ air; 4\% zat penyamak Krom; 3\% zat penyamak Glutaraldehid. Putar campuran diatas selama 60 menit, kemudian buang cairannya.

\section{g. Netralisasi}

R/ $100 \%$ air; $2 \%$ Natrium Asetat, putar selama 10 menit; tambahkan $1 \%$ Natrium Format, putar 10 menit; tambahkan 1,5\% Natrium Bicarbonat, putar 45 menit, kemudian buang cairannya; $\mathrm{pH}=5,5$. 
h. Pencucian

$\mathrm{R} / 200 \%$ air panas $(100 \mathrm{C})$; Cuci kulit dalam drum selama 10 menit, kemudian buang cairannya.

i. Peminyakan

R/ $0 \%$ air (sisa pencucian); $8 \%$ Corripal DX 902; $10 \%$ Cromopol 4FB/W; $2 \%$ Coconut Oil; Buat pasta dan langsung masukkan dalam drum. Putar selama 90 menit, tambah dengan

R/ $100 \%$ air panas $(80 \mathrm{C}) ; 1 \%$ Asam Formiat, putar 10 menit; tambahkan $0,2 \%$ Anti Jamur, putar 10 menit kemudian buang cairannya.

j. Pengeringan, Pelemasan, Pementangan, Pengkilapan dan pengukuran.

3. Pengujian

Kulit hasil penelitian diuji secara fisis meliputi kekuatan tarik, pertambahan mulur, persen pertambahan mulur, dan kekuatan sobek.

4. Pengolahan Data

Analisa data uji menggunakan statistik rancangan acak lengkap, pola searah (CRD), dan apabila hipotesa 0 ditolak pengujian diteruskan dengan analisa perbandingan ganda menurut Newman-Kenls.

\section{HASIL DAN PEMBAHASAN}

Hasil uji rata-rata kekuatan tarik, pertambahan mulur, persen pertambahan mulur, dan ketahanan sobek dapat dibuat pada tabel berikut :

\section{Tabel Hasil Uji Rata-rata Kulit Sarung Tangan Pada Berbagai Kecepatan}

\section{Drum}

\begin{tabular}{|l|l|c|c|c|}
\hline No. & Kecepatan & 15 RPM & 20 RPM & 25 RPM \\
& Jenis Uji & & & \\
\hline 1. & Kekuatan tarik (Kg/cm2) & 114,95 & 127,92 & 138,56 \\
2. & Pertambahan Mulur (mm) & 17,20 & 23,20 & 29,30 \\
3. & Persen Pertambahan Mulur (\%) & 34,40 & 46,40 & 58,60 \\
4. & Ketahanan Sobek (Kg/cm) & 23,45 & 26,93 & 30,53 \\
\hline
\end{tabular}

Dalam penelitian ini drum yang digunakan mempunyai diameter 1,12 m. Apabila dihitung secara matematis, maka :
42,4

$$
\begin{aligned}
& \mathrm{Nc}=\sqrt{1,12} \\
& \mathrm{NR}=1 / 2 \mathrm{Nc}=20,038 \mathrm{RPM} \\
& \mathrm{NI}=2 / 3 \mathrm{Nc}=26,906 \mathrm{RPM}
\end{aligned}
$$

Artinya apabila drum diputar dengan kecepatan rotasi 40,359 RPM, kulit tidak akan pernah jatuh pada dasar drum dan sebaliknya bila diputar dengan kecepatan rotasi dibawah 20,038 RPM, kulit seolah-olah hanya menggelinding, tidak terbanting, karena pada ketinggian dibawah lubang tengah drum kulit sudah tergelincir kebawah.

Pada kecepatan rotasi 26,906 RPM maka aksi mekanik yang diperoleh kulit maksimum. Namun demikian perlu diperhatikan bahwa aksi mekanik tidak hanya tergantung pada kecepatan rotasi drum, tapi juga oleh besarnya beban yang ada dalam drum. Dalam hal ini kulit tidak jatuh langsung ke dasar drum tetapi pada cairan yang digunakan dalam drum, sehingga maksimum impact speed juga akan berbeda-beda tergantung pada beban yang ada, walaupun kecepatan rotasi dan diameter drum sama besarnya.

Dalam penelitian ini masing-masing kelompok mempunyai berat yang hampir sama masing-masing $2,169 \mathrm{~kg}, 2,167 \mathrm{~kg}$, dan $2,166 \mathrm{~kg}$ sehingga pengaruh beban terhadap aksi mekaniknya dianggap sama.

\section{Kekuatan tarik}

Dari hasil uji statistik kekuatan tarik, dapat dilihat bahwa uji $\mathrm{F}$ atau $\mathrm{F}$ hitung $>\mathrm{F}$ tabel, dimana F hitung 4,92 dan $\mathrm{F}$ tabel 3,88 pada tingkat keyakinan $95 \%$. Hal ini berarti ada perbedaan nyata antara kuat tarik kulit yang diputar pada 15 RPM, 20 RPM, dan 25 RPM. Semakin tinggi putarannya kekuatan tarik semakin tinggi. Pada kecepatan 25 RPM rata-rata hasil ujinya sebesar $138,559 \mathrm{~kg} / \mathrm{cm}$ dengan standar penyimpangan 4,373 , sedangkan kekuatan tarik pada kecepatan 15 RPM sebesar $114,9506 \mathrm{~kg} / \mathrm{cm}$ dengan standar penyimpangan 18,427. Disini tampak bahwa pada kecepatan 15 RPM sebaran datanya sangat tidak merata bila dibandingkan dengan standar penyimpangan 4,373. Dapat diasumsikan ini sebagai akibat distribusi dan difusi bahan kimia kedalam kulit tidak merata, demikian pula reaksi yang terjadi. A kibatnya sifat bagian-bagian kulit yang satu dengan yang lainnyapun berbeda. Pada kecepatan 15 RPM kulit hanya terangkat sedikit dan segera menggelinding ke dasar drum. Bahkan tampak menjadi satu gulungan (seperti bola) tidak terpisah satu dengan yang lain. Sebaliknya pada kecepatan 25 RPM kulit terangkat sampai diatas lubang drum dan kemudian jatuh terbanting pada dasar drum. 


\section{Pertambahan mulur dan persen pertambahan mulur}

Seperti halnya dengan kekuatan tarik kulit, hasil uji statistik pertambahan mulur dan persen pertambahan mulur menunjukkan adanya perbedaan nyata diantara perlakuan dengan $\mathrm{F}$ hitung masing-masing 10,39 dan 13,61. Dari rata-rata hasi uji dapat dilihat adanya kenaikan nilai rata-rata. Disini kulit mempunyai kemuluran yang semakin tinggi seiring dengan kenaikan putaran kecepatan drum. Pada kecepatan rotasi yang lebih tinggi (25 RPM) kulit juga terbanting lebih sering dan lebih tinggi. Disini difusi minyak masuk lebih dalam dan lebih terdistribusi secara merata. Secara teoritis dikatakan bahwa jumlah minyak yang terdapat di dalam kulit mempunyai korelasi yang positif terhadap fleksibilitas kulit, termasuk sifat kemuluran.

\section{Ketahanan sobek}

Hasil uji statistik juga menunjukkan adanya perbedaan yang nyata pada ketahanan sobek kulit diantara perlakuan dengan F terhitung sebesar 43,36. Ratarata hasil uji menunjukkan adanya hubungan atau korelasi positif, dimana semakin tinggi putarannya semakin tinggi ketahanan sobeknya berarti kulit bertambah ulet. Dengan difusi yang tidak sempurna berarti bahan kimia terutama minyak tidak sampai masuk ke penampang serat kulit. Pada saat terjadi dehidrasi bagian tersebut akan melekat lengket satu sama lainnya, karena tidak adanya sistim lubrikasi minyak antar serat sehingga serat akan lebih kaku, keras, dan rengas seperti halnya daun yang kering, mudah patah atau putus apabila mendapat gaya tidak terlalu kuat.

Apabila kita tinjau dari kecepatan idealnya (26,906 RPM) maka dari hasil penelitian ini dapat dilihat bahwa pada putaran 25 RPM (mendekati kecepatan ideal) hasil ujinya mempunyai karakter fisik yang lebih baik dibanding dengan yang diproses pada putaran 15 RPM dan 20 RPM.

\section{KESIMPULAN}

1. Hipotesa $\mathrm{Nol}(\mathrm{Ho})$ ditolak dan Hipotesa $1(\mathrm{H} 1)$ diterima berarti ada perbedaan nyata pada perlakuan.

2. Dari variasi kecepatan drum yang dilakukkan maka kulit yang diproses menggunakan drum dengan kecepatan 25 RPM memberikan hasil uji rata-rata yang lebih baik, dengan kekuatan tarik $138,56 \mathrm{~kg} / \mathrm{cm} 2$, pertambahan mulur 29,30 $\mathrm{mm}$, persen pertambahan mulur $58,60 \%$ dan ketahanan sobek $30,53 \mathrm{~kg} / \mathrm{cm}$.

\section{DAFTAR PUSTAKA}

1. Anonim, Leather Technical Pocket Book, Ludwigshafen, Amrhein, BASF, 1990.

2. Anonim, Leather Dyer's Manual, Ludwigshafen, Amrhein, BASF, 1989.
3. Bienkiewwicz.K., Physical Chemistry of Leather Making, Leather Publishing Company Malabar Florida, 1993.

4 Judoamijaya.M., Defek-defek pada Kulit Mentah dan Kulit Samak, Bharata Karya Aksara, Jakarta, 1981

5. O'Flaherty, The Chemistry and technology of Leather, Reinhold Publishing Corporation, New York, 1958

6. Sharpouse.JH., Leather Technician Hand Books, Leather Producer's Association, Northamton, London, 1971.

7. Sharpouse.JH., Leather Technician Hand Books, Leater Producer's Association, Kings Park Road, Northamton, London, 1989.

8. Subriman, Machine Operation in Leather Manufacture, Central Leather Research Institute, Adyar Madras, 1979.

9. Sugandi dkk, Rancangan Percobaan Teori dan Apikasi, Andi Offset, Yogyakarta, 1994.

10. Wordroffe, M.Sc., Handbook on Chrome Tanning, Quality Books Teynmonth,S. Devan, England, 1958 